\title{
MODEL PERSEDIAAN PEMASOK-PEMBELI DENGAN PRODUK CACAT DAN KECEPATAN PRODUKSI TERKONTROL
}

\author{
NELITA PUTRI SEJATI, WAKHID AHMAD JAUHARI, DAN CUCUK NUR ROSYIDI \\ Jurusan Teknik Industri - Universitas Sebelas Maret \\ Jl. Ir Sutami 36 A, Surakarta 57126, Indonesia \\ Surel: nelitaputri@gmail.com, wachid_aj@yahoo.com,cucuknur@gmail.com
}

\begin{abstract}
ABSTRAK
Penelitian ini mengembangkan model persediaan Joint Economic Lot Size (JELS) pada pemasok tunggal pembeli tunggal untuk jenis produk tunggal dengan mempertimbangkan produk cacat dan tingkat produksi terkontrol. Tingkat permintaan pada pembeli bersifat stokastik. Pengiriman dilakukan dari pemasok ke pembeli dalam ukuran lot pengiriman yang sama dan lead time pengiriman bersifat tetap. Produk cacat yang ditemukan oleh pembeli pada saat inspeksi disimpan secara sementara di gudang pembeli hingga pengiriman berikutnya tiba untuk selanjutnya produk cacat dikembalikan kepada pemasok. Fungsi tujuan dari model ini adalah meminimasi total biaya persediaan gabungan pemasok pembeli dengan variabel keputusan, yaitu frekuensi pengiriman, periode review, dan tingkat produksi. Analisis sensitivitas dilakukan untuk melihat pengaruh perubahan parameter-parameter tertentu terhadap model. Hasil yang didapatkan dari analisis sensitivitas menunjukkan bahwa total biaya persediaan gabungan sensitif terhadap perubahan nilai parameter persentase produk cacat, ketidakpastian permintaan, dan permintaan.
\end{abstract}

Kata Kunci : persediaan, permintaan stokastik, produk cacat, tingkat produksi terkontrol

\begin{abstract}
In this paper, we consider a joint economic lot size (JELS) model consisting of single vendor single buyer with single product. We intend to study the impact of defective items and controllable production rate on the model. The demand in buyer side is assumed to be stochastic. The delivery of lot from vendor to buyer is conducted under equal size shipment and the lead time is assumed to be constant. The defective items founded by the inspector in buyer side are carried in buyer's storage until the next shipment and will be returned to the vendor. The goal of the proposed model is to determine optimal delivery frequency, review period and production rate by minimizing the joint total cost. A sensitivity analysis is performed to show the impact of the changes of the decision variables on model's behavior. The result from the sensitivity analysis shows that the joint total cost is sensitive to the changes of defect rate, demand uncertainty and demand rate.
\end{abstract}

Key words: inventory, stochastic demand, defective items, controllable production rate

\section{PENDAHULUAN}

Pada model persediaan tradisional, keputusan ukuran lot produksi pada produsen, dan ukuran lot pemesanan oleh pembeli ditentukan secara independen. Dengan kata lain, masing-masing pihak menentukan sendiri keputusannya sehingga berorientasi pada keuntungan masing-masing. Pendekatan semacam ini akan merugikan salah satu pihak, oleh karena itu pengambilan keputusan mengalami perkembangan dimana tidak lagi dilakukan secara independen melainkan terintegrasi yang melibatkan seluruh pihak yang terkait di dalam supply chain. Produsen dan pembeli bekerjasama dalam menentukan ukuran lot gabungan yang diharapkan dapat meminimasi total biaya gabungan. Model persediaan Joint 
Economic Lot Size (JELS) yang mengintegrasikan seluruh pihak terkait dalam supply chain untuk menentukan ukuran lot gabungan dilakukan pertama kali oleh Goyal (1976). Goyal (1976) mampu membuktikan bahwa dengan adanya ukuran lot ekonomis gabungan menimbulkan pengurangan biaya yang cukup signifikan dalam supply chain. Penelitian tersebut diikuti dan dikembangkan oleh beberapa peneliti lain seperti Banerjee (1986) dan Lu (1995) dengan berbagai parameter yang merupakan pengembangan dari penelitian sebelumnya.

Penelitian di atas (Goyal, 1976; Banerjee, 1986; dan Lu, 1995) menggunakan asumsi bahwa lead time dan tingkat produksi bernilai tetap. Jauhari (2012) mengembangkan sebuah model persediaan JELS pada sistem pemasok tunggal pembeli tunggal dimana permintaan pada pihak pembeli bersifat stokastik dengan melakukan sinkronisasi siklus pemesanan oleh pembeli, produksi oleh pemasok, dan pengadaan bahan baku yang mempertimbangkan tingkat produksi pada pihak pemasok yang bersifat terkontrol. Besarnya tingkat produksi bervariasi dan terbatas di antara $P_{\min }$ dan $P_{\text {max }}\left(P_{\min }<P<P_{\max }\right)$. Untuk menjamin bahwa kapasitas produksi dapat memenuhi seluruh permintaan, maka diasumsikan bahwa nilai dari tingkat produksi lebih besar daripada permintaan $\left(P_{\min }>D\right)$.

Beberapa model persediaan di atas, tidak ada yang mempertimbangkan adanya produk cacat yang dikirim oleh pemasok kepada pembeli. Lin (2010) mengembangkan sebuah model persediaan stokastik terintegrasi pada supplier-retailer. Pada penelitian ini, Lin mempertimbangkan adanya produk cacat yang diproduksi oleh supplier untuk retailer. Dengan pertimbangan tersebut, retailer melakukan inspeksi terhadap produk yang datang dengan kecepatan tertentu $(x)$, sehingga pada proses tersebut menimbulkan biaya inspeksi $(s)$. Jika ukuran lot pengiriman adalah sebesar $D T$ dan di dalam setiap satu lot pengiriman yang tiba di retailer terdapat produk cacat dengan persentase tetap yaitu $\gamma$, maka besarnya produk cacat yaitu $\gamma D T$ dan besarnya produk tidak cacat adalah $(1-\gamma) D T$.
Produk cacat disimpan terlebih dahulu di gudang retailer hingga waktu pengiriman berikutnya tiba, setelah itu dikembalikan kepada supplier. Oleh sebab itu, retailer menanggung biaya simpan untuk produk cacat dan produk tidak cacat. Lin (2010) menyimpulkan jika persentase dari produk cacat yang ada di setiap lot pengiriman dari supplier kepada retailer meningkat, maka akan mengakibatkan peningkatan biaya total persediaan gabungan per tahun pada sistem. Lin (2010) belum mempertimbangkan tingkat produksi yang terkontrol. Oleh karena itu, penelitian ini bertujuan untuk mengembangkan model persediaan JELS yang mempertimbangkan produk cacat berdasarkan penelitian Lin (2010), dan tingkat produksi terkontrol berdasarkan penelitian Jauhari (2012). Pada penelitian ini hubungan antara jumlah produk cacat yang dihasilkan dari sistem produksi dan tingkat produksi yang terkontrol akan diteliti lebih dalam. Adanya fleksibilitas sistem untuk menentukan tingkat produksi optimal tentunya akan membantu supplier untuk mengelola berapa jumlah batch yang harus diproduksi dengan memperhatikan jumlah produk cacat yang dihasilkan.

\section{PENGEMBANGAN MODEL}

Penelitian ini membahas tentang model persediaan JELS pemasok tunggal pembeli tunggal untuk produk tunggal dimana permintaan produk pada pembeli bersifat stokastik dan berdistribusi normal. Tingkat produksi pada pemasok dapat dikontrol berdasarkan kebutuhan tertentu, misalnya permintaan yang meningkat dari periode sebelumnya. Besarnya tingkat produksi bervariasi dan terbatas di antara $P_{\text {min }}$ dan $P_{\max }\left(P_{\min }<P<P_{\max }\right)$. Pembeli mengelola persediaannya secara periodik dengan lead time pemesanan bersifat variabel, dimana besarnya lead time bergantung pada lama proses produksi dan pengiriman.

Pada model ini pembeli melakukan pemesanan kepada pemasok sebesar $D T$ dengan frekuensi pengiriman sebanyak $m$ kali dengan lot pengiriman $q(D T)$. Untuk memenuhi permintaan 
pembeli, pemasok melakukan produksi sebanyak $m q(m D T)$. Selanjutnya pemasok melakukan pengiriman kepada pembeli sebanyak $q$ untuk setiap periodenya. Pengiriman tersebut mulai dapat dilakukan ketika proses produksi sudah menghasilkan minimal sejumlah $q$, sehingga tidak perlu menunggu satu batch $(m q)$ produk selesai diproduksi. Pembeli melakukan inspeksi terhadap produk yang dikirim oleh pemasok untuk mengklasifikasikan produk cacat dan tidak cacat. Inspeksi dilakukan dengan kecepatan sebesar $x$ dan menyebabkan pembeli mengeluarkan biaya inspeksi produk per unit $(C)$. Persentase produk cacat per pengiriman diasumsikan tetap sebesar $\gamma$, sehingga besarnya produk tidak cacat adalah sebesar 1- $\gamma$. Produk cacat akan disimpan sementara di gudang pembeli hingga pengiriman berikutnya tiba, selanjutnya dikembalikan kepada pemasok. Oleh karena itu, pembeli menanggung biaya penyimpanan produk tidak cacat $\left(H_{b 1}\right)$ dan produk cacat $\left(H_{b 2}\right)$, sedangkan pemasok menanggung biaya perawatan produk cacat (v). Gambar 1 menunjukkan model persediaan pada pemasok dan pembeli.

Asumsi yang digunakan pada model ini adalah sebagai berikut :

1. Permintaan pada pihak pembeli bersifat stokastik dan berdistribusi normal.

2. Tingkat produksi diasumsikan lebih besar daripada permintaan $\left(P_{m i n}>D\right)$ untuk menjamin bahwa kapasitas produksi dapat memenuhi permintaan dan terbatas oleh nilai

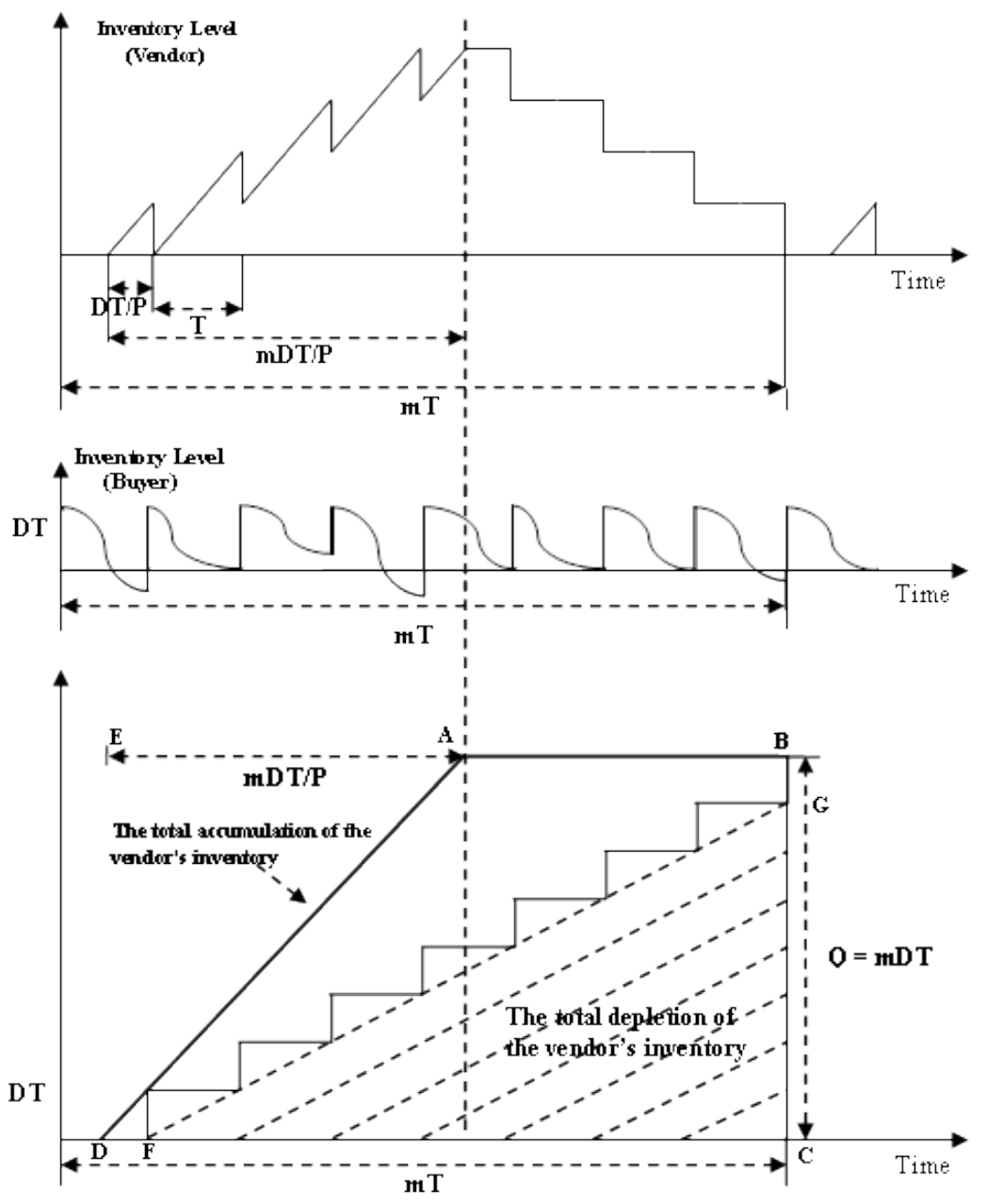

Gambar 1. Profil Persediaan Pemasok dan Pembeli 
minimal dan maksimal $\left(P_{\min }<\mathrm{P}<P_{\max }\right)$.

3. Proporsi produk cacat bernilai tetap.

4. Lead time bersifat tetap

Notasi yang digunakan dalam model ini sebagai berikut:

$\mathrm{Q}=m q=$ lot size per production run

$D \quad=$ rata-rata permintaan pembeli per tahun

$\delta=$ standar deviasi permintaan per tahun

$P \quad=$ kecepatan produksi pada pemasok, $P>D$

$q=$ lot size per pengiriman dari pemasok ke pembeli

$m \quad=$ frekuensi pengiriman per $q$ dari pemasok ke pembeli ( $m \in$ positive integer)

$S \quad=$ biaya setup per production run

$A \quad=$ biaya pemesanan per periode pada pembeli

$F \quad=$ biaya transportasi per periode dari pemasok ke pembeli

$b \quad=$ lama waktu pengiriman dari pemasok ke pembeli

$\gamma=$ persentase produk cacat setiap pengiriman, $0 \leq \gamma<1$

$x \quad=$ kecepatan inspeksi

$C \quad=$ biaya inspeksi per unit pada pembeli

$h_{v} \quad=$ biaya simpan per unit per tahun pada pemasok

$H_{b 1} \quad=$ biaya simpan produk tidak cacat per unit per tahun pada pembeli

$H_{b 2} \quad=$ biaya simpan produk cacat per unit per tahun pada pembeli

$v=$ biaya perawatan produk cacat per unit

$=$ biaya backorder per unit

= safety factor

$=$ review period

$=$ biaya produksi tetap per unit

$=$ biaya produksi variabel per unit

Fungsi tujuan dari penelitian ini adalah ekspektasi total biaya gabungan $(T C j)$ yang terdiri dari total biaya persediaan pemasok $(T C v)$ dan total biaya persediaan pembeli (TCb).

\section{Formulasi Biaya Pemasok}

Total ekspektasi biaya pemasok didapatkan dari penjumlahan beberapa komponen biaya, diantaranya yaitu biaya setup produksi $\left(S_{v} C\right)$, biaya produksi $(P C)$, biaya penyimpanan pemasok $\left(H C_{v}\right)$, biaya perawatan produk cacat $(T d C)$. Biaya penyimpanan pada pemasok mengacu pada penelitian Lin (2010) :

$H C_{v}=\left\{\frac{(n-2) D T}{2}\left(1-\frac{D}{P}\right) h_{v}+\frac{D T}{2} h_{v}\right\}$

Total ekpektasi biaya pemasok dapat diformulasikan dengan menambahkan biaya setup produksi, biaya produksi, dan biaya perawatan produk cacat, sehingga didapatkan formulasi 2 sebagai berikut :

$$
\begin{aligned}
& T C_{v}=\left\{\frac{S_{v}}{n T}\right\}+\left\{\left(\frac{a_{1}}{P}+a_{2} P\right) D\right\} \\
& +\left\{\frac{(n-2) D T}{2}\left(1-\frac{D}{P}\right) h_{v}+\frac{D T}{2} h_{v}\right\}+\{v \gamma D\}
\end{aligned}
$$

\section{Formulasi Biaya Pembeli}

Total ekspektasi biaya pembeli didapatkan dari penjumlahan biaya pemesanan $(O C)$, biaya transportasi $\left(T_{r} C\right)$, biaya penyimpanan $\left(H C_{b}\right)$, biaya shortage $\left(S_{h} C\right)$, dan biaya screening $\left(S_{c} C\right)$. Biaya penyimpanan pembeli mengacu pada penelitian Lin (2010), dimana mencakup biaya penyimpanan produk tidak cacat $\left(H C_{b 1}\right)$ dan biaya penyimpanan produk cacat $\left(H_{b 2}\right)$ :

$$
\begin{aligned}
& H C_{b 1}=\left[\frac{1}{2}(1-\gamma) D T^{2}\right] h_{r 1} \\
& =\left[\frac{D T^{2}}{2}-\frac{\gamma D T^{2}}{2}\right] h_{r 1} \\
& H C_{b 2}=\left[\gamma D T \frac{D T}{X}\right] h_{r 2} \\
& =\left[\frac{\gamma(D T)^{2}}{X}\right] h_{r 2}
\end{aligned}
$$

Formulasi ekspektasi jumlah backorder mengacu pada penelitian Lin (2010). Adapun besarnya biaya shortage merupakan perkalian 
biaya backorder $(\pi)$ dengan ekspektasi jumlah backorder dalam satu periode yang ditunjukkan dalam persamaan 5 berikut ini :

$S_{h} C=\left\{\left(\frac{1}{T} \psi(k) \sigma \sqrt{T+L}\right) \pi\right\}$

Dimana :

$\psi(k)=\left\{f_{s}(k)-k\left[1-F_{s}(k)\right]\right\}$

Dengan Fs (k) merupakan cumulative distribution function dari safety factor $k$ dan $f s$ (k) merupakan probability density function dari safety factor $k$ untuk distribusi normal standar dengan rata-rata 0 dan standar deviasi 1.

Dengan menambahkan biaya pemesanan, biaya transportasi, dan biaya screening didapatkan formulasi total ekspektasi biaya pembeli sebagai berikut :

$$
\begin{aligned}
& T C_{B}\left(n^{*}, P^{*}, T^{*}\right)=\left\{\frac{A}{T}\right\}+\left\{\frac{F}{T}\right\}+\left\{\frac{H_{b 1}}{T}\left[\frac{D T^{2}}{2}(1-\gamma)\right]\right. \\
& \left.+\frac{H_{b 2}}{T}\left[\frac{\gamma(D T)^{2}}{X}\right]\right\}+\left\{\left(\frac{1}{T} \psi(k) \sigma \sqrt{T+L}\right) \pi\right\}+\{C D\} .
\end{aligned}
$$

\section{Formulasi Biaya Total Gabungan}

Biaya total gabungan untuk pemasok dan pembeli diformulasikan dengan menjumlahkan total ekpektasi biaya pada pemasok dan pembeli. Formulasinya ditunjukkan pada persamaan 9 .

$$
\begin{aligned}
& T C_{j}\left(n^{*}, P^{*}, T^{*}\right)=\left\{\frac{S}{n T}\right\}+\left\{\left(\frac{a_{1}}{P}+a_{2} P\right) D\right\} \\
& +\left\{\frac{(n-2) D T}{2}\left(1-\frac{D}{P}\right) h_{v}+\frac{D T}{2} h_{v}\right\}+\{v \gamma D\}+\left\{\frac{A}{T}\right\}+\left\{\frac{F}{T}\right\} \\
& +\left\{\frac{H_{b 1}}{T}\left[\frac{D T^{2}}{2}(1-\gamma)\right]+\frac{H_{b 2}}{T}\left[\frac{\gamma(D T)^{2}}{x}\right]\right\} \\
& +\left\{\left(\frac{1}{T} \psi(k) \sigma \sqrt{T+L}\right) \pi\right\}+\{C D\}
\end{aligned}
$$

\section{METODOLOGI SOLUSI}

Dalam sub bab ini akan dikembangkan metodologi solusi untuk mencari solusi optimal dari variabel keputusan biaya total gabungan $T C_{j}\left(m^{*}, P^{*}, T^{*}\right)$. Dengan nilai $m$ yang tetap, maka $T C_{j}\left(m^{*}, P^{*}, T^{*}\right)$ akan mencapai nilai minimum pada titik $(P, T)$ yang memenuhi persamaan 9 dan 10 secara simultan.

$\frac{\partial T C_{j}\left(m^{*}, P^{*}, T^{*}\right)}{\partial P}=0$

dan

$\frac{\partial T C_{j}\left(m^{*}, P^{*}, T^{*}\right)}{\partial T}=0$

\section{Variabel Keputusan $\boldsymbol{P}$}

Penentuan nilai optimal dari variabel keputusan $P$ (tingkat produksi) dilakukan penurunan parsial pertama pada persamaan $T C_{j}\left(m^{*}, P^{*}, T^{*}\right)$ terhadap $P$ yang memenuhi persamaan 9 .

Didapatkan formulasi tingkat produksi optimal $\left(P^{*}\right)$ sebagai berikut:

$P^{*}=\sqrt{\frac{2 a_{1}+D T(2-m) h_{v}}{2 a_{2}}}$

Penurunan parsial kedua $T C_{j}\left(m^{*}, P^{*}, T^{*}\right)$ terhadap $P$ dilakukan untuk membuktikan bahwa besarnya $P$ optimal yang dicari menggunakan penurunan parsial pertama adalah terbukti benar optimal dengan memenuhi ketentuan

$\frac{\partial T C_{j}\left(m^{*}, P^{*}, T^{*}\right)}{\partial P^{2}}>0$

serta nilai $m$ dan $T$ tetap.

$\frac{\partial T C_{j}\left(m^{*}, P^{*}, T^{*}\right)}{\partial P}=\frac{2 a_{1} D+2 D^{2} T(2-m) h_{v}}{P^{3}}$ 


\section{Variabel Keputusan $T$}

Penentuan nilai optimal dari variabel keputusan $T$ (review period) dilakukan penurunan parsial pertama pada persamaan $T C_{j}\left(m^{*}, P^{*}, T^{*}\right)$ terhadap $T$.

$$
\begin{aligned}
& \frac{\partial T C_{j}\left(m^{*}, P^{*}, T^{*}\right)}{\partial T}=-\left\{\frac{S}{m T^{2}}\right\}+\left\{\frac{D h_{v}}{2}\left(\frac{D(2-m)}{P}+(m-1)\right)\right\} \\
& -\left\{\frac{A}{T^{2}}\right\}-\left\{\frac{F}{T^{2}}\right\}+\left\{\left(\frac{H_{b 1} D(1-\gamma)}{2}\right)+\left(\frac{H_{b 2} D^{2} \gamma}{x}\right)\right\} \\
& +\left\{\frac{-\sigma \psi(k) \pi \sqrt{T+L}}{T^{2}}+\frac{\sigma \psi(k) \pi}{2 T \sqrt{T+L}}\right\} \ldots \ldots \ldots \ldots \ldots \ldots \ldots \ldots \ldots \ldots \ldots \ldots \ldots
\end{aligned}
$$

Dengan menggunakan persamaan 10 didapatkan formulasi tingkat produksi optimal $\left(T^{*}\right)$ sebagai berikut:

$$
T^{*}=\sqrt{\frac{S+m A+m F+m \sigma \psi(k) \pi \sqrt{T+L}}{m\left\{\frac{D h_{v}}{2}\left(\frac{D(2-m)}{P}+(m-1)\right)+\frac{H_{b 1} D(1-\gamma)}{2}+\frac{H_{b 2} D^{2} \gamma}{x}+\frac{\sigma \psi(k) \pi}{2 T \sqrt{T+L}}\right\}}}
$$

Pencarian solusi terhadap nilai $m^{*}, P^{*}$ dan $T^{*}$ untuk mendapatkan total biaya persediaan gabungan yang minimum dapat dilakukan dengan menggunakan suatu algoritma. Algoritma yang dibuat mengacu pada algoritma yang telah dikembangkan oleh Jauhari dkk. (2011).

Langkah 1 : Menetapkan $n=1$ dan TC (n-1) $=\infty$

Langkah 2 : Menghitung nilai $P$ awal dengan formulasi sebagai berikut :

$$
P_{0}=\sqrt{\frac{a_{1}}{a_{2}}}
$$

Langkah 3: Langkah selanjutnya adalah menghitung besarnya $T_{\text {awal }}$ dengan cara mensubstitusikan besarnya $P_{0}$ ke dalam formulasi $T_{0}$, dimana pada formulasi tersebut telah dihilangkan variabel $T$ di dalamnya.
$T_{0}=\sqrt{\frac{s+m A+m F+m \sigma \psi(k) \pi \sqrt{T+L}}{m\left\{\frac{D h_{v}}{2}\left(\frac{D(2-m)}{P_{0}}+(m-1)\right)+\frac{H_{b 1} D(1-\gamma)}{2}+\frac{H_{b 2} D^{2} \gamma}{x}+\frac{\sigma \psi(k) \pi}{2 T \sqrt{T+L}}\right\}}}$

Langkah 4 : Menghitung nilai $P$ dengan mensubstitusikan nilai $P_{0}$ dan $T_{0}$ ke dalam formulasi berikut ini :

$$
P^{*}=\sqrt{\frac{2 a_{1}+D T_{0}(2-m) h_{v}}{2 a_{2}}} \ldots \ldots
$$

Langkah 5 : Menghitung $T$ dengan mensubstitusikan nilai $P$ dan $T_{0}$ ke dalam formulasi berikut ini

$$
T^{*}=\sqrt{\frac{s+m A+m F+m \sigma \psi(k) \pi \sqrt{T+L}}{m\left\{\frac{D h_{v}}{2}\left(\frac{D(2-m)}{P}+(m-1)\right)+\frac{H_{b_{1}} D(1-\gamma)}{2}+\frac{H_{b 2} D^{2} \gamma}{x}+\frac{\sigma \psi(k) \pi}{2 T \sqrt{T+L}}\right\}}}
$$

Langkah 6 : Membandingkan nilai $T_{\text {sebelum }}$ dengan $T_{\text {sesudah }}$ dan $P_{\text {sebelum }}$ dengan $P_{\text {sesudah }}$, jika nilai $T_{\text {sebelum }}$ dengan $T_{\text {sesudah }}$ dan $P_{\text {sebelum }}$ dengan $P_{\text {sesudah }}$ sudah konvergen, maka iterasi untuk nilai $n$ yang sama dihentikan. Sebaliknya, jika belum maka iterasi dilanjutkan hingga nilai $\mathrm{T}$ dan $\mathrm{P}$ konvergen.

Langkah 7 : Menghitung nilai $T C_{\text {total }}$ dengan memasukkan hasil perhitungan nilai $T$ dan $P$ yang sudah konvergen ke dalam formulasi $T C_{\text {total }}$ berikut ini :

$$
\begin{aligned}
& T C_{\text {total }}=\left\{\frac{s}{m T}\right\}+\left\{\left(\frac{a_{1}}{P}+a_{2} P\right) D\right\} \\
& +\left\{\frac{(m-2) D T}{2}\left(1-\frac{D}{P}\right) h_{v}\right\}+\left\{\frac{D T}{2} h_{v}\right\} \\
& +\{v \gamma D\}+\left\{\frac{A}{T}\right\}+\left\{\frac{F}{T}\right\}+\left\{\frac{H_{b_{1}}}{T}\left[\frac{D T^{2}}{2}(1-\gamma)\right]\right. \\
& \left.+\frac{H_{b 2}}{T}\left[\frac{\gamma(D T)^{2}}{X}\right]\right\}+\left\{\left(\frac{1}{T} \psi(k) \sigma \sqrt{T+L}\right) \pi\right\}+\{C D\}
\end{aligned}
$$


Langkah 8 : Selanjutnya dilakukan iterasi lagi mulai dari langkah 1 dengan $(\mathrm{m}+1)$

- Jika hasil $T C_{m+1}$ lebih besar dari $T C_{m}$, maka iterasi dihentikan.

- Jika hasil $T C_{m+1}$ lebih kecil dari $T C_{m}$, iterasi dilanjutkan dengan penambahan nilai $m$ menjadi $(m+1)$ dan iterasi akan berhenti jika $T C_{m+1}$ lebih besar dari $T C_{m}$

\section{CONTOH NUMERIK}

Contoh numerik yang akan diberikan mengacu pada model Jauhari dkk. (2011).

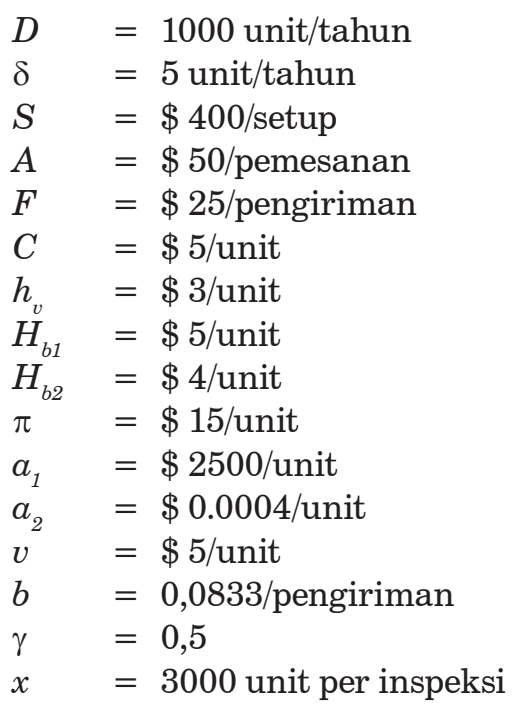

Tabel 1. Pengaruh Persentase Produk Cacat terhadap Model

\begin{tabular}{lrrrrr}
\hline & \multicolumn{5}{c}{ Persentase Cacat (g) } \\
\cline { 2 - 6 } & $\mathbf{0 , 1}$ & $\mathbf{0 , 2}$ & $\mathbf{0 , 3}$ & $\mathbf{0 , 4}$ & $\mathbf{0 , 5}$ \\
\hline Frekuensi Pengiriman (Kali/periode) & 9 & 9 & 9 & 9 & 8 \\
Review Period (Hari) & 30 & 31 & 31 & 31 & 34 \\
Tingkat Produksi (Unit/periode) & 1500 & 1500 & 1500 & 1500 & 2113 \\
Biaya Perawatan Produk Cacat $(\$)$ & 500,00 & $1.000,00$ & $1.500,00$ & $2.000,00$ & 2500,00 \\
Total Biaya Pemasok (\$) & 5.950 & 4.449 & 4.949 & 5.448 & 5.643 \\
Total Biaya Pembeli $(\$)$ & 5.574 & 5.564 & 5.553 & 5.542 & 5.515 \\
Total Biaya Gabungan $(\$)$ & 9.524 & 10.013 & 10.502 & 10.990 & 11.158 \\
B. Simpan Tidak cacat $(H C b 1)(\$)$ & 188 & 168 & 147 & 127 & 133 \\
B. Simpan cacat (HCb2) $(\$)$ & 11 & 22 & 34 & 45 & 71 \\
Total Biaya Simpan Pembeli $(\$)$ & 199 & 190 & 181 & 172 & 204 \\
\hline
\end{tabular}

Tabel 2. Pengaruh Variasi Standar Deviasi Permintaan terhadap Model

\begin{tabular}{rcccccc}
\hline $\mathbf{s}$ & $\boldsymbol{m}$ & $\mathbf{T}$ & $\boldsymbol{P}$ & $\begin{array}{c}\text { Biaya } \\
\text { Pembeli }\end{array}$ & $\begin{array}{c}\text { Biaya } \\
\text { Pemasok } \\
\mathbf{( \$ )}\end{array}$ & $\begin{array}{c}\text { Biaya } \\
\text { Gabungan } \\
\mathbf{( \$ )}\end{array}$ \\
\hline 5 & 9 & 0,084 & 1500 & 5.553 & 4.949 & 10.502 \\
10 & 9 & 0,085 & 1500 & 5.561 & 4.948 & 10.509 \\
15 & 6 & 0,118 & 2624 & 5.557 & 4.698 & 10.255 \\
20 & 6 & 0,118 & 2622 & 5.564 & 4.698 & 10.262 \\
25 & 6 & 0,118 & 2621 & 5.570 & 4.698 & 10.269 \\
30 & 5 & 0,136 & 2678 & 5.587 & 4.689 & 10.275 \\
\hline
\end{tabular}

Tabel 3. Pengaruh Variasi Permintaan terhadap Model

\begin{tabular}{rrrcrrr}
\hline $\boldsymbol{D}$ & $\boldsymbol{m}$ & $\boldsymbol{T}$ & $\boldsymbol{P}$ & $\begin{array}{c}\text { Biaya } \\
\text { Pembeli } \\
\mathbf{( \$ )}\end{array}$ & $\begin{array}{c}\text { Biaya } \\
\text { Pemasok } \\
\mathbf{( \$ )}\end{array}$ & $\begin{array}{c}\text { Biaya } \\
\text { Gabungan } \\
\mathbf{( \$ )}\end{array}$ \\
\hline 500 & 4 & 0,22 & 2832 & $2.910,80$ & $2.643,10$ & $5.553,90$ \\
750 & 4 & 0,18 & 2790 & $4.265,40$ & $3.682,80$ & $7.948,20$ \\
1000 & 5 & 0,14 & 2678 & $5.586,70$ & $4.688,60$ & $10.275,30$ \\
1250 & 7 & 0,10 & 2491 & $6.899,90$ & $5.644,10$ & $12.544,00$ \\
1500 & 10 & 0,08 & 2158 & $8.211,80$ & $6.534,70$ & $14.746,50$ \\
\hline
\end{tabular}


$k=1,645$

$\psi(k)=0,561$

Solusi optimal yang didapatkan berdasarkan perhitungan contoh numerik menggunakan program Matlab 2009a, yaitu $\mathrm{m}=8 \mathrm{kali}, \mathrm{T}=$ 34 hari, $\mathrm{P}=2113$ unit/periode dan total biaya gabungan $\$ 11.158$.

Tabel 1 memberikan gambaran mengenai pengaruh persentase produk cacat terhadap model. Dari tabel tersebut dapat dilihat bahwa dengan meningkatnya persentase produk cacat memberikan pengaruh yang signifikan terhadap peningkatan biaya persediaan pada pemasok dan biaya persediaan gabungan. Pada pihak pembeli, terjadi peningkatan biaya penyimpanan produk cacat lebih besar dibandingkan penurunan biaya penyimpanan produk tidak cacat. Hal tersebut menyebabkan biaya persediaan pada pembeli cenderung menurun seiring peningkatan persentase produk cacat. Dari Tabel 1 juga dapat dilihat bahwa frekuensi pengiriman dan review period cenderung tetap seiring meningkatnya persentase produk cacat.

Tabel 2 menunjukkan pengaruh perubahan ketidakpastian permintaan terhadap model. Dapat kita lihat bahwa semakin besar ketidakpastian permintaan menyebabkan frekuensi pengiriman semakin kecil. Pada Tabel 2 terlihat juga bahwa review period dan tingkat produksi semakin besar nilainya sering meningkatnya ketidakpastian permintaan. Sedangkan biaya total gabungan mengalami penurunan, hal ini disebabkan oleh penurunan biaya persediaan pemasok lebih besar dibandingkan dengan peningkatan biaya persediaan pembeli.

Tabel 3 memperlihatkan bahwa peningkatan permintaan memberikan pengaruh yang signifikan terhadap variabel-variabel keputusan dan fungsi tujuan dari model. Frekuensi pengiriman meningkat secara signifikan seiring dengan meningkatnya jumlah permintaan, sedangkan review period dan tingkat produksi mengalami penurunan. Baik biaya persediaan pada pembeli maupun pada pemasok, keduanya mengalami peningkatan yang signifikan, sehingga biaya total gabungan ikut meningkat dengan perubahan nilai yang cukup besar.

\section{SIMPULAN}

Pada penelitian ini dikembangkan model persediaan pemasok tunggal pembeli tunggal dengan mempertimbangkan produk cacat dan tingkat produksi terkontrol. Lead time diasumsikan tetap dan besarnya permintaan mengikuti distribusi normal. Dalam penelitian ini juga mengasumsikan bahwa setiap lot produk yang dikirim dari pemasok ke pembeli terdapat produk cacat dengan persentase yang tetap. Penelitian ini bertujuan untuk mendapatkan nilai variabel keputusan yang optimal yang meliputi frekuensi pengiriman, review period, dan tingkat produksi, serta meminimasi biaya total gabungan. Hasil yang didapatkan dari analisis perubahan nilai parameter terhadap model dapat disimpulkan bahwa total biaya gabungan sensitif terhadap perubahan persentase produk cacat, ketidakpastian permintaan, dan jumlah permintaan. Frekuensi pengiriman dan tingkat produksi mengalami penurunan ketika nilai persentase produk cacat dan ketidakpastian permintaan mengalami peningkatan. Sebaliknya, ketika permintaan mengalami peningkatan, frekuensi permintaan ikut meningkat. Hal yang serupa terjadi pada tingkat produksi. Sedangkan biaya gabungan mengalami peningkatan yang signifikan ketika persentase produk cacat dan permintaan semakin besar nilainya, akan tetapi biaya total gabungan menurun ketika terjadi peningkatan nilai ketidakpastian permintaan.

\section{DAFTAR PUSTAKA}

Banerjee, A., 1986. A Joint Economic-Lot-Size Model for Purchaser and Vendor, Decision Sciences, 17(3), 292-311.

Goyal, S.K., 1976. An Integrated Inventory Model for a Single Supplier - Single Customer Problem, International Journal of Production Research, 15(1), 107-111.

Jauhari, W.A., Pujawan, I.N., Wiratno, S.E., and Priyandari, Y., 2011. Integrated Inventory Model 
for Single Vendor-Single Buyer with Probabilistic Demand, International Journal of Operational Research, 11(2), 160-178.

Jauhari, W.A., 2012. Integrated Inventory Model for Three-layer Supply Chain with Stochastic Demand, International Journal of Operational Research, 13(3), 295-317.
Lin, Y.J., 2010. A Stochastic Periodic Review Integrated Inventory Model Involving Defective Items, Backorder Price Discount, and Variable Lead Time, 4OR, 8, 281-297.

Lu, L., 1995. A One-vendor Multi-buyer Integrated Inventory Model, European Journal of Operational Research, 81(2), 312-323. 